\title{
ISOLATION AND SOME CHARACTERISTICS OF PLACENTAL ALKALINE PHOSPHATASE
}

\author{
HIROSHI KAWASAKI, YOSHIHIRO AKAGI AND TAKASHI MIYAMOTO \\ Institute of Clinical Pathology, Kurume University School of Medicine, \\ Kurume, 830, Japan
}

\author{
EIJI KIMOTO, AKIKO TAKADA, JUNKO YASUNAGA \\ AND KATSUKI YANO \\ Department of Chemistry, Faculty of Science, Fukuoka University, \\ Fukuoka, 814, Japan
}

(Received for publication January 24, 1977)

\begin{abstract}
Placental alkaline phosphatase was found to be heterogeneous in respect of its gel electrophoretic migration and molecular weight. It hampered the purification of this enzyme.

The present authors devised the isolation procedure to obtain this enzyme in a sufficiently pure state and in large quantity. The process included the removal of protein impurities with Japanese acid clay and carboxymethyl cellulose, and affinity chromatography on L-phenylalaninecoupled Sepharose 4B and then on concanavalin A-labeled Sepharose 4 B.

The carbohydrate content of purified enzyme preparation was as low as 6 per cent, of which major components were glucosamine and mannose. Oligosaccharide chains of this enzyme were responsible for the interaction with concanavalin A, even after exoglycosidase digestion.

This enzyme possessed $\alpha$-helical conformation, as documented by optical rotatory dispersion and circular dichroism measurement. This ordered conformation persisted in an alkaline solution, though it was destroyed with a simultaneous loss of activity in an acidic solution.
\end{abstract}

\section{INTRODUCTION}

Serum alkaline phosphatase isoenzyme of cancer patient with bronchogenic carcinoma was discovered, by Fishman et al. $(1968 \mathrm{a}, \mathrm{b})$, to contain an alkaline phosphatase [or thophosphoric monoester phosphohydrase, E. C. 3, I, 3, I] which was indistinguishable from placental isoenzyme in the properties of high sensitivity to the stereo-specific inhi- bitor, L-phenylalanine, heat stability and characteristic migration on starch gel electrophoresis.

Our immunohistological studies (Kawasaki et al., 1974), using the fluorescein isothiocyanate-labeled antibody against purified placental alkaline phosphatase, revealed that carcinoma cells of the stomach and rectum were fluorescent along their cell borders and within their cytoplasms while the in- 
testinalized gastric epithelium, stromal elements and endothelial cells of blood capillaries were devoid of specific fluorescence. Sharp distinction in isoenzyme pattern between carcinoma cells and their surrounding areas was demonstrated.

Placental alkaline phosphatase isoenzyme was thus qualified as an example of ectopic antigen production or embryonic gene expression of malignant cells.

This enzyme has yet been crystallized (Ghosh and Fishman, 1968 ; Harkness, 1968) and partially characterized as a component of membrane-bound enzymes (Fishman, 1974). The percentage of total carbohydrate residues in the enzyme preparation was reported by Ghosh et al. (1968) to account as high as 25-30 par cent. Sialic acid, fucose, hexosamine (both of glucosamine and galactosamine), mannose, galactose and glucose were assumed to be an integral part of the enzyme molecule. It was deduced to belong to a kind of sialoprotein. Harkness (Harkness, 1968) did not mention its carbohydrate composition.

The role of cell surface in the biological behavior of cancer cell has been one of the continued interest in recent years (Winzler, 1970). The properties of membrane glycoproteins were thought to represent an important aspect of neoplastic transformation.

By means of affinity chromatography, using the L-phenylalanine-coupled Sepharose 4B as devised recently by Doellgast and Fishman (1974) and concanavalin A-labeled Sepharose 4 B

(Aspberg and Parath, 1970), the present authors have developed a purification procedure of this enzyme and investigated some chemical and physicochemical characteristics based upon its membrane-bound character.

\section{EXPERIMENTAL}

Extraction of placental alkaline phosphatase

Pooled fullterm placental tissue $e_{\text {s }}$ were homogenized in 5 volumes of $0.01 \mathrm{M}$ citrate buffer of $\mathrm{pH} 5.5$ containing 0.05 $\mathrm{M} \mathrm{NaCl}$ and 1 per cent of butanol in the cold. It was repeated twice with freezing and thawing. After centrifugation, the supernatant was isolated and the sediment was extracted twice with the same buffer solution. Alkaline phosphatase in tissues was almost completely extractable by these treatments. The combined supernatant of dark red color was mixed with a specify amount of Japanese acid clay until it became pale.

Carboxymethyl-cellulose (Serva, capacity : $0.64 \mathrm{meq} / \mathrm{g}$ ) was activated in the usual way and bufferized in the citrate buffer solution. To $1,000 \mathrm{ml}$ of the above extract, $100 \mathrm{~g}$ (wet weight) of carboxymethyl-cellulose was added and stirred for one hour. The supernatant was filtered through the Seitz filter disc made of asbestos, pore size 5 microns (Toyo Kagaku Sangyo, Osaka). The filtrate thus obtained was completely colorless and transparent. A loss of enzyme activity, by these treatments, was not significant.

The filtrate was mixed with 4 volumes of ethanol containing 0.5 per cent of sodium acetate. After leaving it in the cold for 3 days, the resulting precipitate was collected by centrifugation, washed with ethanol and then acetone, and dried in a $\mathrm{CaCl}_{2}$ desiccator. From one $\mathrm{Kg}$ (wet weight) of the placenta, about one $\mathrm{g}$ of dry powder, crude enzyme preparation, was obtained.

\section{Assay for enzyme activity}

Enzyme activity was measured according to the method of Bessey-Lowry- 
Brock (1946).

Enzyme solution $(0.1 \mathrm{ml})$ was mixed with the substrate solution $(0.5 \mathrm{ml})$ containing $60 \mathrm{mM}$-disodium p-nitrophenyl phosphate and $5 \mathrm{mM}-\mathrm{MgCl}_{2}$ in 0.05 $\mathrm{M}$ glycine buffer of $\mathrm{pH} 10.5$. After incubation at $37^{\circ} \mathrm{C}$ for 30 minutes, the assay mixture was added with $5 \mathrm{ml}$ of $0.02 \mathrm{~N} \mathrm{NaOH}$. The amount of liberated nitrophenol was measured colorimetrically at $405 \mathrm{~m} \mu$. One unit of activity was defined as that which liberated $1 \mu$ mol of nitrophenol in 30 minutes.

Denaturation of this enzyme in an acidic solution was examined. After exposing the enzyme to different $\mathrm{pH}$ at room temperature for 3 hours and then neutralizing, the activity was assayed as above.

\section{Isozlectric forcusing}

The isoelectric point was determined by the isoelectric forcusing, according to the method of Svensson (1962). LKB ampholine column of $110 \mathrm{ml}$ capacity and ampholine carrier ampholyte, covering $\mathrm{pH}$ range between 5 and 8 , were employed. A potential of 1,000 volts was applied for 48 hours. A current was 10 $\mathrm{mA}$ at the start and $1.5 \mathrm{~mA}$ in the final. The content of the column was drained into $3 \mathrm{ml}$ fractions, after which the enzyme activity and $\mathrm{pH}$ of the fractions were measured.

The applied enzyme sample was 332 units and the enzyme assay was carried out on the 3-times diluted solutions of drained fractions.

\section{Polyacrylamide gel disc electrophoresis}

The disc electrophoresis was conducted in $0.6 \times 7 \mathrm{~cm}$ glass column according to the method of Davis (1964). Enżyme sample solution, added with a trace amount of brom phenol blue as a marker, was mixed with $1 / 3$ volume of glycerol and $0.2 \mathrm{ml}$ of this mixture was layered on the upper gel in a column immediately before electrophoresis. A power supply of $2.5 \mathrm{~mA}$ per column was applied.

After electrophoresis, the gel was removed from a column and stained for enzyme activity and protein. The activity was stained with using p-toluidinium 5-bromo-4-chloro-3-indoxyl-phosphate (purchased from Midori Juji Co., Osaka) as a substrate, in buffer solution of $\mathrm{pH} 10.2$ containing $2 \times 10^{-3} \mathrm{M}$ $\mathrm{MgCl}_{2}$ and $2 \mathrm{M}$ 2-amino-2-methyl-1,3propanediol. Another gel was counterstained with Amidoblack $10 \mathrm{~B}$.

\section{Gel filtration}

It was carried out according to the method of Laurent and Killander (1964). Sephadex G-100 (a product of Pharmacia, Uppsala, Sweden) was equilibrated with $0.2 \mathrm{M}$ sodium acetate solution and packed into a column of $2.6 \mathrm{~cm}$ diameter to a hight of $100 \mathrm{~cm}$. Thirty $\mathrm{mg}$ of sample, dissolved in $10 \mathrm{ml}$ of sodium acetate solution, was applied to a column, eluted with the same solution at a flow rate of $40 \mathrm{ml}$ per hour, and $10 \mathrm{ml}$ fractions were collected. The eluates were assayed for enzyme activity.

On the same column and at the same condition as above, human serum was run as a reference.

\section{Hydrophobic affinity chromatography using L-phenylalanine-coupled Sepha- rose $4 B$}

The retention of placental alkaline phosphatose on L- or D-phenylalaninecoupled Sepharose column, was found by Doellgast and Fishman (1974). Retention on a column was greatest at a high concentration of ammonium sulfate. The ammonium sulfate-mediated 
retention related to the hydrophobic character of the substituted Sepharose, rather than to any specific binding site of the enzyme. It was suggested that this provides a way of controlling the hydrophobic affinity chromatography (Hjertén, 1973).

In this experiment, the CNBr-activated Sepharose $4 \mathrm{~B}$ and its conjugate with L-phenylalanine were prepared according to the method of Axén et al. (1967). One g (dry weight) of the conjugated Sepharose was determined, after hydrolysis and amino acid analysis, to possess $14.3 \mathrm{mg}$ of L-phenylalanine.

The crude enzyme solution was dissolved in $0.05 \mathrm{M}$ Tris-acetate buffer of $\mathrm{pH} 7.5$ containing $1.2 \mathrm{M}$ ammonium sulfate. Fifty $\mathrm{ml}$ of one per cent enzyme solution $(500 \mathrm{mg}$ of crude preparation possessing approximately 20,000 units of enzyme activity) was applied on a column $(2.6 \times 50 \mathrm{~cm})$ of L-phenylalanine-coupled Sepharose 4 B. It was washed with $375 \mathrm{ml}$ of ammonium sulfate-containing buffer solution. And then it was eluted with $375 \mathrm{ml}$ of $1.2 \mathrm{M}$ $\mathrm{NaCl}$-containing buffer solution. Fifteen $\mathrm{ml}$ of the effluent solution was collected and assayed for enzyme activity and optical density at $280 \mathrm{~m} \mu$.

\section{Chromatography on concanavalin A- labeled Sepharose $4 B$}

This procedure was carried out according to the method of Aspberg and Porath (1970). Concanavalin A-labeled Sepharose 4B was purchased from Pharmacia Fine Chem., Sweden. It was washed with saline solution, containing 0.001 $\mathrm{M}$ each of $\mathrm{CaCl}_{2}$ and $\mathrm{MnCl}_{2}$ (SCM solution), and packed into a column $(2 \times 26$ $\mathrm{cm})$. Twenty $\mathrm{ml}$ of enzyme solution $(10,000$ units) was introduced into a column. After washing the bed with 20 $\mathrm{ml}$ of SCM solution, the column was left overnight in the cold with stopping the elution. Next day, the washing was continued with $100 \mathrm{ml}$ of SCM solution. The elution of enzyme was performed with $0.1 \mathrm{M}$ methyl- $\alpha$-D-mannopyranoside - containing SCM solution. The effluents were collected in $10 \mathrm{ml}$ fractions, which were assayed for enzyme activity and for an UV absorption.

\section{Analytical methods}

Constituent amino acids were determined in an Amino Acid Analyser JLC$6 \mathrm{AH}$, JEOL, Tokyo, after hydrolysis of a sample in $6 \mathrm{~N} \mathrm{HCl}$ at $100^{\circ} \mathrm{C}$ for 24 hours in an evacuated tube. Sulfurcontaining amino acids were analysed after performic acid oxidation of a sample by the method of Hirs (1967).

Total hexose value was determined by the orcinol-sulfuric acid method of Winzler (1955). Sialic acid was determined by the thiobarbituric acid method of Warren (1959) after hydrolysing a sample in $0.1 \mathrm{~N}$ sulfuric acid at $80^{\circ} \mathrm{C}$ for one hour. Individual hexoses were separated and estimated by the gasliquid chromatography according to the method of Tamura et al. (1968). Sample was hydrolysed in $0.5 \mathrm{~N}$ sulfuric acid, followed by the reduction of sugars to corresponding alcohols and trifluoroacetylation.

Hexosamines were analysed by the Amino Acid Analyser after hydrolysing a sample with $4 \mathrm{~N} \mathrm{HCl}$ for 8 hours in an evacuated tube. Column length was $25 \mathrm{~cm}$. Citrate buffer of $\mathrm{pH} 5.28(\mathrm{Na}$ : $0.35 \mathrm{~N}$ ) was employed.

Infrared absorption spectrum was obtained on a Grating Infrared Spectrophotometer, JASCO IRA-I, Tokyo, to see the absorption bands of sulfate groups.

\section{Treatment with glycosidase}

Concanavalin A was reported (So and 
Goldstein, 1967) to possess the specific binding sites capable of interacting with polysaccharide chains of $\alpha$-D-mannopyranoside and $\alpha$-D-glucopyranoside configurations. Effect of specific exoglycosidases on the response of placental alkaline phosphatase to concanavalin A was investigated.

The $\alpha$-mannosidase from Jack beans $[\alpha-\mathrm{D}$-mannoside mannohydrase, EC 3. 2. 1. 24] was purchased from Boehringer Mannheim Biochem. One mg of this enzyme liberated $583 \mu \mathrm{g}$ of free phenol from phenyl- $\alpha-\mathrm{D}$-mannoside for one hour at $37^{\circ} \mathrm{C}$.

Crude enzyme, preparation $\mathrm{S} 2$, from abalone liver was obtained according to the method of Tanaka et al. (1968). One $\mathrm{mg}$ of enzyme liberated $18 \mu \mathrm{g}$ of free phenol from phenyl- $\alpha$-D-mannoside, $3 \mu \mathrm{g}$ phenol from phenyl- $\alpha$-D-galactoside, $2 \mu \mathrm{g}$ phenol from phenyl- $\alpha$-Dglucoside, $1 \mu \mathrm{g}$ phenol from phenyl- $\alpha$ L-fucoside, $1 \mu \mathrm{g}$ phenol from phenyl$\mathrm{N}$-acetyl- $\beta$-D-glucosaminide in $0.1 \mathrm{M}$ citrate buffer of $\mathrm{pH} 5.3$ for one hour at $37^{\circ} \mathrm{C}$.

Liberated reducing sugars, after incubation of placental alkaline phosphatase with abalone enzyme or $\alpha$-D-mannosidase, was determined by the method of Park-Johnson (1949), using glucose as a standard.

\section{Optical activity measurement}

Measurements of optical rotatory dispersion (ORD) and circular dichroism (CD) in the ultraviolet region were carried out with a JASCO Model J-20 Automatic Recording Spectropolarimeter at $23^{\circ} \mathrm{C}$.

The light path length of the cell was $1 \mathrm{~cm}$. The protein concentration was 50 $\mu \mathrm{g} / \mathrm{ml}$. Measurements were done in acidic, neutral and alkaline solutions within 3 hours after $\mathrm{pH}$ arrangement.

The specific rotation, $(\alpha)$, and re- duced dichroism, $\mathrm{E}_{1 \mathrm{~cm}}^{1 \%}$, were plotted against wave length.

$$
\begin{gathered}
(\alpha)=\alpha / 1 \mathrm{c}, 1=0.1 \text { deci } \mathrm{m}, \\
\mathrm{c}=0.00005 \mathrm{~g} / \mathrm{ml}
\end{gathered}
$$

\section{RESULTS}

Isoelectric forcusing experiment (Fig. 1) indicated that placental alkaline phosphatase was condensed into an isoelectric zone of $\mathrm{pH}$ 4.7. So, this enzyme might be slightly negative-charged at $\mathrm{pH}$ 5.5, in which the crude enzyme extract was treated with Japanese acid clay and carboxymethyl-cellulose. Such a low pI value would be responsible for this enzyme to be free from binding to these cation adsorbents in a slightly acidic solution. At this $\mathrm{pH}$ condition, these adsorbents were quite useful to remove most of positive-charged protein impurities and colored substances in the crude extract.

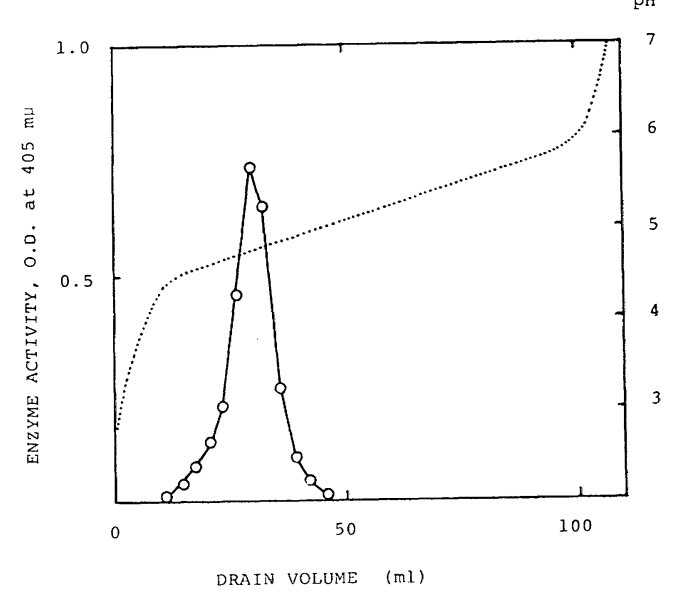

Fig. I Alkaline phosphatase activity and $\mathrm{pH}$ of the fractions taken from a $110 \mathrm{ml}$ column after is electric forcusing.

- o- : enzyme activity, expressed as the optical density at $405 \mathrm{~m} \mu$ after Bessey-Lowry-Brock reaction. $: \mathrm{pH}$ value. 


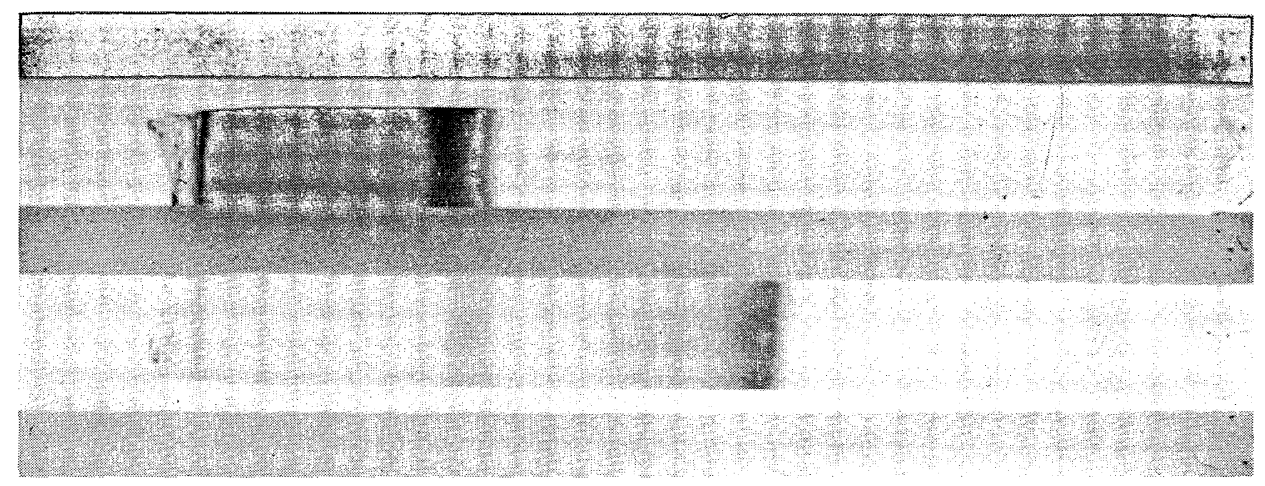

Fig. 2 Disc electrophoretic pattern of placental alkaline phosphatase.

Upper gel was stained for enzyme activity. The activity pattern was nearly the same between crude preparation and purified ones by means of L-phenylalanine-coupled Sepharose chromatography and further by concanavalin A-labeled Sepharose chromatography.

Lower gel was stained for proteins on the sample prepared by L-phenylalaine-coupled Sepharose chromatography. On a sample purified by concanavalin A-labeled Sepharose chromatography, any protein bands were scarcely demonstrated.

Fig. 2 indicated the disc electrophoretic pattern of crude enzyme preparation. Broad enzyme band of the highest activity migrated nearly as fast as serum transferrin as a reference. Several enzyme bands of less activity were also demonstrated in the lower mobility region. Several protein bands, which did not coincide with any enzyme bands, were also present. They might be impurities.

Elution profile of placental alkaline phosphatase in gel filtration on Sephadex G-100 was indicated in Fig. 3. It showed that this enzyme existed mainly in two molecular weight variants of 70,000 and about 200,000 dalton, as published by Ghosh and Fishman (1968).

Thus, placental alkaline phosphatase was recognized to be heterogeneous in respect of electrophoretic migration in gel and molecular weight. An affinity chromatography directed toward its characteristically interacting groups

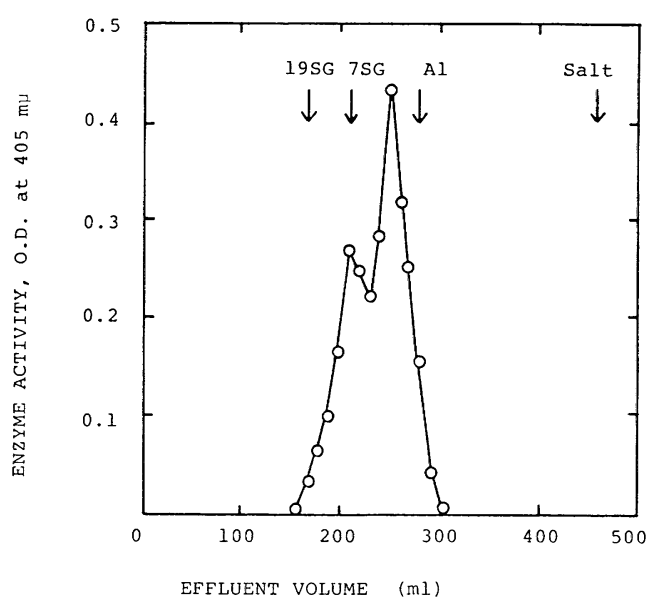

Fig. 3 Gel filtration on Sephadex G-100. Effluent volumes of serum proteins and salt, as a reference, are indicated by arrows. 19SG : 19S globulin, 7SG : 7SG globulin, $\mathrm{Al}$ : albumin, Salt: salt volume.

was, therefore, employed for the purification of this enzyme. 


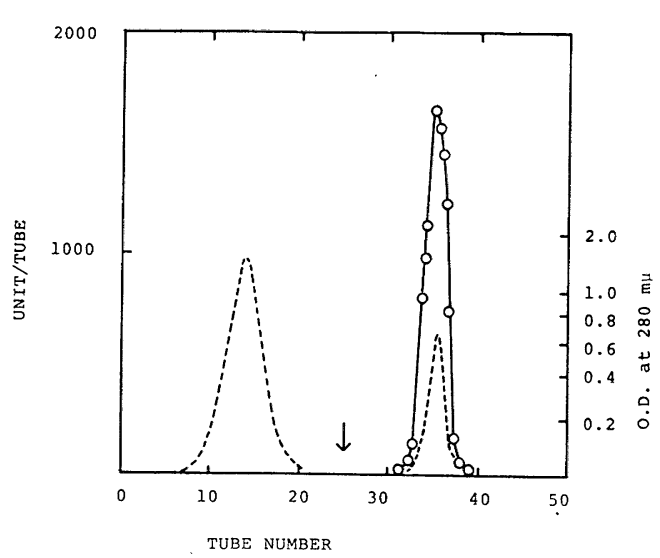

Fig. 4 Elution profile of alkaline phosphatase on L-phenylalanine-labeled Sepharose $4 \mathrm{~B}$.

-o- : enzyme activity, unit per tube.

-- : optical density at $280 \mathrm{~m} \mu$.

Arraw indicates the position changing the eluting solution from 1.2 M ammonium sulfate to $1.2 \mathrm{M} \mathrm{NaCl}$.

On the column of L-phenylalaninecoupled Sepharose, placental alkaline phosphatase was completely retarded in $1.2 \mathrm{M}$ ammonium sulfate and eluted in $1.2 \mathrm{M} \mathrm{NaCl}$. Most of protein impurities, showing an UV absorption at 280 $\mathrm{m} \mu$, was excluded from a column in ammonium sulfate solution. The recovery of enzyme in $\mathrm{NaCl}$ solution was about 80 per cent. On the disc electrophoresis (Fig. 2), it showed the same activity pattern as that of crude enzyme preparation while it still contained some protein impurities. Even the protein band, corresponding to the main activity band of the highest mobility, was different in the width with each other.

It was further subjected to concanavalin A-labeled Sepharose column chromatography, as shown in Fig. 5 . Placental alkaline phosphatase in SCM solution was completely adsorbed to a column and eluted with an addition of

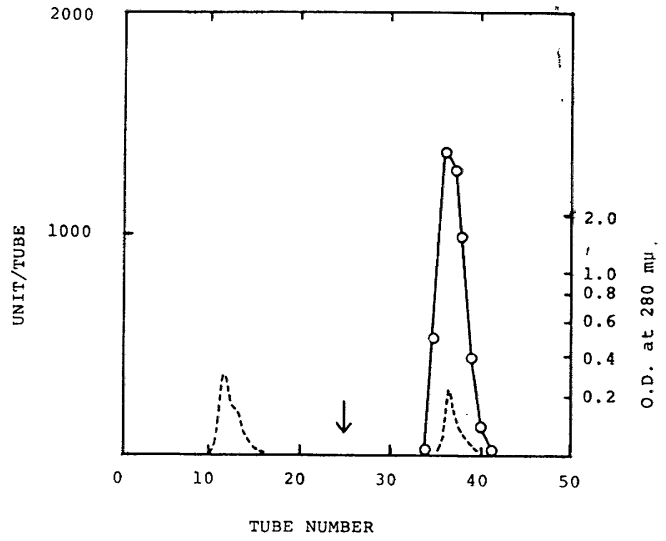

Fig. 5 Chromatography of alkaline phosphatase on concanavalin A-labeled Sepharose 4 B.

The elution was carried out with $250 \mathrm{ml}$ of SCM solution and then with SCM solution containing $0.1 \mathrm{M}$ methyl- $\alpha-\mathrm{D}$-mannopyranose as indicated by arrow.

methyl - $\alpha$-D - mannopyranoside. More than half of protein impurities was eluted in the former fraction. From the latter fraction, with the same activity pattern as that of crude one, any Amidoblack $10 \mathrm{~B}$-stainable bands were scarcely demonstrable in disc electrophoresis. The recovery of enzyme in the latter fraction was 73 per cent.

The enzyme thus purified was dialysed exhaustively against distilled water, lyophilized and subjected to the chemical and physico-chemical analysis.

Though this enzyme preparation was not homogeneous in physico-chemical properties and it composed of two molecular weight variants, it was assumed to be biochemically indistinguishable from each other following to the report of Ghosh and Fishman (1968).

Amino acid and carbohydrate composition of this enzyme was summarized in Table 1.

Relative values of individual amino 
TABLE 1

Amino acid and carbohydrate composition of placental alkaline phosphatase ${ }^{\text {a) }}$

\begin{tabular}{lrlllr}
\hline Asp & 70 & Met & 6 & Glucosamine & 6 \\
Thr & 39 & I le & 18 & Galactosamine & 0 \\
Ser & 95 & Leu & 40 & Hexose & 48 \\
Glu & 141 & Tyr & 23 & Sialic acid & 1 \\
Pro & 32 & Phe & 28 & Fucose & 1 \\
Gly & 58 & Lys & 51 & & \\
Ala & 48 & His & 30 & & \\
Cys & 8 & Arg & 35 & & \\
Val & 38 & & & & \\
\hline
\end{tabular}

a) Figures are indicated as $\mu \mathrm{g}$ per mg material.

One $\mathrm{mg}$ of this material possesses the enzymatic activity of 294 units.

Recovery was 82 per cent.

acids were nearly equal to those reported by Ghosh et al. (1968) and Harkness (1968). In the chart of basic amino acids on Amino Acid Analyser, however, small peak corresponding to ornitine appeared just before lysine peak.

Glucosamine content was only as low as 0.6 per cent, but galactosamine was not detectable. Neutral hexose value was about 5 per cent, but sialic acid content was less than 0.1 per cent. In an infrared spectrum, an absorption band at $1240 \mathrm{~cm}^{-1}$, corresponding to $\mathrm{S}=0$ stretching vibration, was not demonstrable. Though this enzyme possessed the low pI value, acidic groups such as sialic acid and sulfate ester were only in a trace amount.

Placental alkaline phosphatase was reported (Ghosh and Fishman, 1968) to be a sialoprotein. However, the amount of carbohydrate of the enzyme has been the subject of conflicting reports, as mentioned by Warnes (1972). It is conceivable that the discrepancy resulted from steps employed for enzyme extraction and from purity of enzyme preparation. Or, it might also be possible that the enzyme exists in the cell membrane with different amounts of carbo- hydrate attached.

Gas chromatography of constituent neutral sugars revealed that mannose was the most abundant, galactose and glucose were far less in amount, but fucose was scarcely demonstrable.

One hundred $\mathrm{mg}$ of placental alkaline phosphatase, after incubation with 20 $\mathrm{mg}$ of abalone enzyme for 8 hours, liberated $237 \mu \mathrm{g}$ of reducing sugar. And the same amount of this preparation, after incubation with $10 \mathrm{mg}$ of $\alpha-\mathrm{D}$ mannosidase for 8 hours, liberated 110 $\mu \mathrm{g}$ of reducing sugar. These glycosidases should have enough activity, as judged by the digestion assay on the synthetic substrates, to remove most of carbohydrate residues in the phosphatase molecule. But they removed only 2-4 per cent. These glycosidase treatments did not cause any recognizable change in the activity of alkaline phosphatase. Likewise the elution profile of placental alkaline phosphatase on concanavalin A-labeled Sepharose column did not change at all ; any phosphatase activity could not be detectable in the fraction eluted through without methyl- $\alpha$-D-mannopyranoside.

Placental alkaline phosphatase, in 
both neutral ( $\mathrm{pH}$ 7.3) and alkaline ( $\mathrm{pH}$ 11.5) solution, exhibited the far ultraviolet Cotton effect (Jirgensons, 1973) characteristic of $\alpha$-helical conformation from the optical rotatory dispersion (Fig. 6) and circular dichroism measurement (Fig. 7). Such a Cotton effect curve disappeared in an acidic solution ( $\mathrm{pH}$ 1.7).

Exposing the enzyme in an acidic solution (Fig. 8), its activity was lost completely below $\mathrm{pH} 3$ and moderately between 3 and 4 . A loss of enzyme

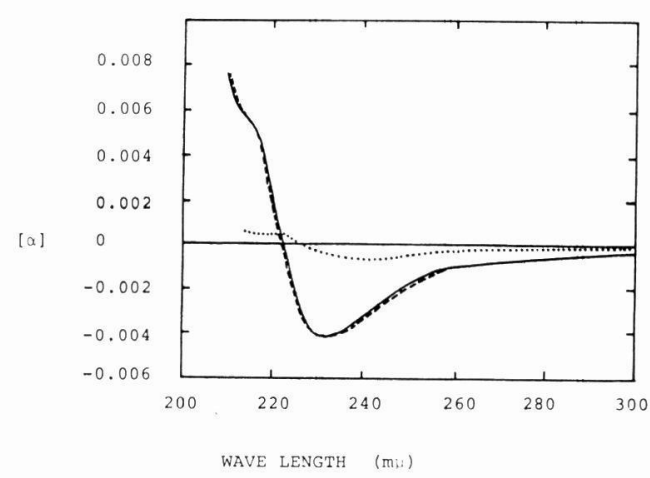

Fig. 6 Ultraviolet optical rotatory dispersion curve of placental alkaline phosphatase.

- : neutral ( $\mathrm{pH} 7.3$ ),

-- : alkaline ( $\mathrm{pH} 11.5)$,

....... : acidic $(\mathrm{pH} 1.7)$.

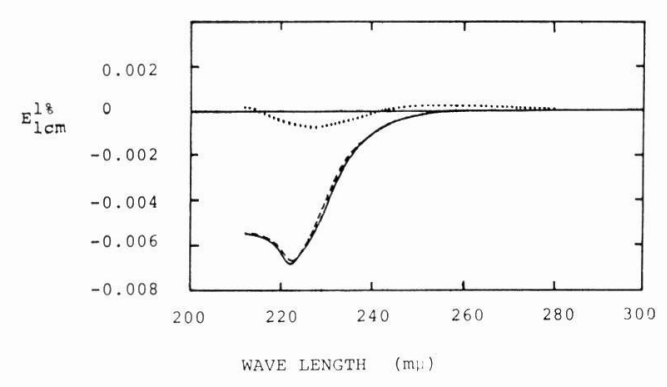

Fig. 7 Circular dichroic spectra of placental alkaline phosphatase.

- : neutral, ---- : alkaline, $\cdots \cdots \cdots \cdot$ acid. activity was coincident with a disappearance of ordered conformation. The ordered $\alpha$-helical structure seemed to be necessary for maintaining the enzyme activity.

The $\mathrm{pH}$ difference absorption spectrum was shown in Fig. 9. On comparing

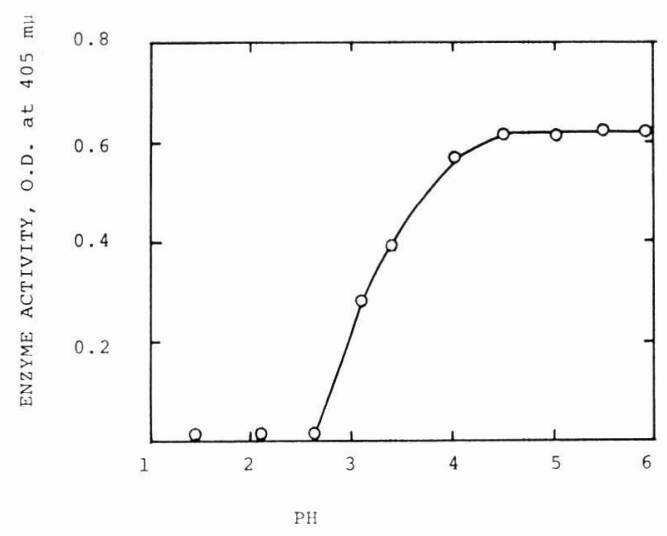

Fig. 8 Change in enzyme activity after explosing in acidic solution.

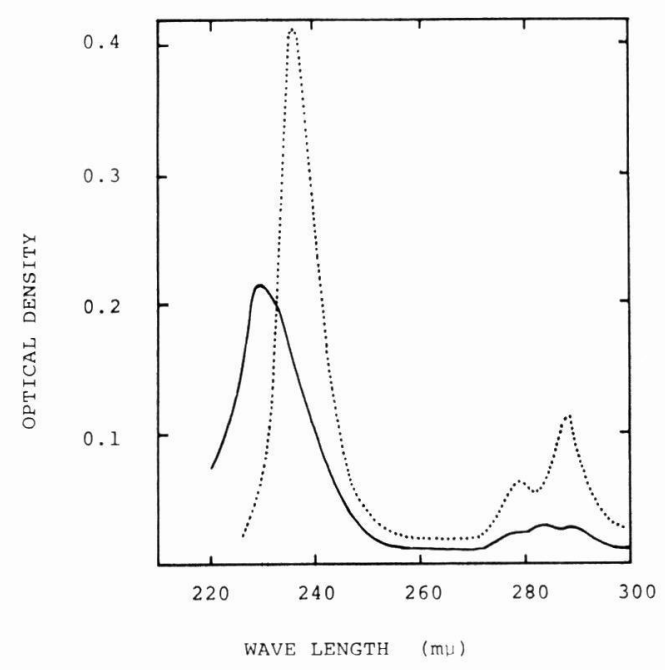

Fig. $9 \mathrm{pH}$ difference absorption spectrum. - : placental alkaline phosphatase, $283 \gamma / \mathrm{ml}$, pH 6.2 vs. pH 1.2.

: bovine serum albumin, $1 \mathrm{mg} / \mathrm{ml}$, pH 5.4 vs. $\mathrm{pH} 1.4$. 
the native with the denatured protein by difference ultraviolet spectroscopy, Glazer and Smith (1960) reported that, in addition to the frequently reported difference peaks due to tyrosine and tryptophan residues at $278 \mathrm{~m} \mu$ to 285 and $293 \mathrm{~m} \mu$ respectively, denaturation was invariably associated with the appearance of a far more prominent peak at $230 \mathrm{~m} \mu$ to $235 \mathrm{~m} \mu$.

Similar to bovine serum albumin, demonstrated as a reference, placental alkaline phosphatase revealed an enhanced difference absorption in a far ultraviolet region in an acidic solution. It would appear likely, from the findings of Glazer and Smith, that the change in the environment of the peptide backbone of protein resulting from denaturation may contribute largely to the observed difference peak.

\section{DISCUSSION}

The primary object of this experiment was to obtain placental alkaline phosphatase in a sufficiently pure state and in a desired amount.

Extraction of this enzyme from placental tissues was successfully achieved in rather a slightly acidic solution which was a little higher in $\mathrm{pH}$ than its isoelectric point. It could be readily subjected to the treatment with Japanese acid clay and carboxymethyl cellulose, which was effective in a slightly acidic solution to remove protein impurities and colored substances.

As placental alkaline phosphatase was found to be heterogeneous in respect of its gel electrophoretic migration and molecular weight, the purification procedure should be mainly depended upon an affinity chromatography.

The L-phenylalanine-coupled Sepharose was first utilized, by Doellgast and Fishman (1974), as a potential adsorbent of placental alkaline phosphatase at high ammonium sulfate concentration. In our experimental condition, 20,000 units of enzyme ( $500 \mathrm{mg}$ of crude enzyme preparation) was completely adsorbed to the column while more than 70 per cent of impure proteins were excluded from a column. The adsorbed enzyme was almost completely eluted in $\mathrm{NaCl}$ solution. On the disc electrophoresis of this fraction (Fig. 2), however, some protein impurities were still contaminated. The method appeared to depend on a non-specific interaction on the hydrophobic phenyl group of phenylalanine with proteins at high ammonium sulfate concentration. This fact was also recognized by Doellgast and Fishman (1974) from an investigation of the binding of this enzyme to Sepharose derivatives of leucine, Dphenylalanine, aniline and $\mathrm{p}$-aminobenzoic acid at this condition.

Placental alkaline phosphatase is one of the membrane-bound enzymes. In human placenta, its activity was found along the plasma membrane lining the microvilli and along the basal surface of the syncytiotrophoblast (Kawasaki et al., 1974 ; Hulstaert et al., 1973). The hydrophobic region of this enzyme molecule might play a role for binding to the membrane.

Further purification of this enzyme was carried out with using concanavalin A-labeled Sepharose. It was found that this enzyme was completely adsorbed to this column and displaced with an addition of methyl- $\alpha$-D-mannopyranoside.

The carbohydrate content of purified enzyme preparation was only as low as 6 per cent, showing a discrepancy with the high carbohydrate value reported by Ghosh et al. (1968), who classified this enzyme as a sialoprotein. As carbohydrate compositions, it lacked in 
sialic acid and fucose, occupying the non-reducing terminals of oligosaccharide chains.

Goldstein and his coworkers (1965) reported that concanavalin $\mathrm{A}$ precipitates certain carbohydrate-containing macromolecules with multiple, nonreducing $\alpha$-mannopyranosyl or $\alpha$-glucopyranosyl residues. This original concept of an exclusive chain end mechanism has been recently modified by these authors (Goldstein et al., 1973). They provided an evidence which demonstrates that concanavalin $A$ may interact with internal $(1 \rightarrow 2)$-linked $\alpha$-D-mannopyranosyl residues.

It seems, from the present results, that placental alkaline phosphatase possesses such specific binding sites in the carbohydrate moieties which could be escaped from exoglycosidase digestion.

Concanavalin A exhibits a wide variety of interesting biological properties. Aspect of the interaction between concanavalin A and cells includes the chemical nature of the concanavalin Abinding sites on the surface of cell membrane and the surface alterations of cells following malignant transformation. Placental alkaline phosphatase, appeared intensely along the cell borders of human carcinoma cells (Kawasaki et al., 1974), might constitute one of the concanavalin A receptor sites on the malignant cell surfaces.

The optimum $\mathrm{pH}$ of this enzyme is higher than 10, though it is generally believed that this enzyme is also active at physiological $\mathrm{pH}$ in its natural environment.

The present experiment proved that the optical activity curves in the ultraviolet region were completely the same between neutral and alkaline solution (even at $\mathrm{pH}$ 11.5) and that this enzyme kept the ordered $\alpha$-helical conformation even in such a high $\mathrm{pH}$ solution. Its conformation was destroyed, however, in an acidic solution with a simultaneous loss of activity. Its ordered conformation seemed to be essential for its enzymatic activity.

\section{REFERENCES}

Aspberg, K. and Porath, J. (1970). Groupspecific adsorption of glycoproteins. Acta Chem. Scandinav., 24, 1839-1841.

Axén, R., Porath, J. and ERnback, S. (1967). Chemical coupling of peptides and proteins to polysaccharides by means of cyanogen halides. Nature, 214, 1302-1304.

Bessey, O.A., LOWRy, O.H. and Brock, M.J. (1946). A method for the rapid determination of alkaline phosphatase with five cubic millimeters of serum. J. Biol. Chem., 164, 321-329.

DAvis, B. J. (1964). Disc electrophoresis. II. Method and application to human serum proteins. Ann. N.Y. Acad. Sci., 121, 404-427.

Doellgast, G. J. and Fishman, W. H. (1974). Purification of human placental alkaline phosphatase. Biochem. J., 141, 103-112.

Fishman, W.H., Inglis, N. R., Green, S., Anstiss, C.L., Ghosh, N.K., Reif, A.E., RustiGIAN, R., KRANT, M.J. and Stolbach, L.L. (1968 a). Immunology and biochemistry of Regan isoenzyme of alkaline phosphatase in human cancer. Nature, 219, 697-699.

Fishman, W. H., Inglis, N.R, Stolbach, L.L. and KRANT, M.J. (1968 b). A serum alkaline phosphatase isoenzyme of human neoplastic cell origin. Cancer Res., 28, 150-154.

Fishman, W. H. (1974). Perspectives on alkaline phosphatase isoenzymes. Am. J. Med. 56, 617-650.

Ghosh, N. K. and Fishman, W. H. (1968). Purification and properties of molecularweight variants of human placental alkaline phosphatase. Biochem. J., 108, 779-792.

GlaZer, A.N. and Smith,E.L. (1960). Effect of denaturation on the ultraviolet absorption spectra of proteins. J. Biol. Chem., 235, PC 43-44.

Goldstein, I. J., Hollerman, C.E. and Merrick, J.M. (1965). Protein carbohydrate interaction. I. The interaction of polysaccharides with concanavalin A. Biochim. Biophys. Acta, 97, 68-76. 
Goldstein, I. J., Reichest, C. M., Misaki, A. and Gorin, P.A.J. (1973). Biochim. Biophys. Acta, 317, 500-504.

HARKNESS, D.R. (1968). Studies on human placental alkaline phosphatase. I. Purification and crystallization. Arch Biochem. Biophys., 126, 503-512.

Hirs, C. H. W. (1967). Enzyme structure. Methods in Enzymol., 11, 197-199.

HJERTÉn, S. (1973). Some general aspects of hydrophobic interaction chromatography. J. Chromatog., 87, 325-331.

Hulstaert, C.E., Torringa, T.L., Kondstall, J., HARDonk, M.J. and Molennar, I. (1973). The characteristic aistribution of alkaline phosphates in the full-term placenta. Gynecol. Invest., 4, 24-30.

JiRgensons, B. (1973). Optical Activity of Proteins and Other Macromolecules. pp. 75-98, Springer-Verlag, New York.

KaWAsaki, H., Takeuchi, M. and Kimoto, E. (1974). Immuncfluorescent staining of placental alkaline phosphatase in gastric and rectal carcinoma. GANN, 65, 473-479.

Laurent, T. C. and Killander, J. (1964). A theory of gel filtration and its experimental verification. J. Chromatog., 14, 317-330.

PARK, J.T. and Johnson, M. J. (1949). A microdetermination of glucose. J. Biol. Chem., 181, 149-151.
So, L.L. and Goldstein, I J. (1967). Proteincarbohydrate interaction. IV. Application of the quantitative precipitin method to polysaccharide-concanavalin A interaction. J. Biol. Chem., 242, 1617-1622.

Svensson, H. (1962). Isoelectric fractionation, analysis, and characterization of ampholytes in natural $\mathrm{pH}$ gradients. III. Description of apparatus for electrolysis in columns stabilized by density gradients and direct determination of isoelectric points. Arch. Biochem. Biophys. Suppl. 1, 132-138.

TAMURA, Z., ImANari, T. and Arakawa, Y. (1968). Gas chromatographic analysis of sugars in glycoproteins. Proc. Symp. Chem. Physiol., 8, 72-75.

TANaka, K., NaKano, T., Noguchi, S. and PigMAN, W. (1968). Purification of $\alpha$-L-fucosidase of abalone livers. Arch. Biochem. Biophys., 126, 624-633.

Warnes, T. W. (1972). Alkaline phosphatase. Gut, 13, 926-937.

WARren, L. (1959). The thiobarbituric acid assay of sialic acids. J. Biol. Chem., 234, 1971-1975.

WiNZLER, R.J. (1955). Determination of serum glycoproteins. Methods Biochem. Analysis, 2, 279-306.

Winzler, R. J. (1970). Carbohydrates in cell surfaces. Intern. Rev. Cytology, 29, 77-125. 